\title{
POR UMA POÉTICA NA INFÂNCIA: OS VERSOS N'A CALIGRAFIA DE DONA SOFIA
}

\author{
Amanda Moura \\ Doutoranda em Literatura Comparada pela Universidade Federal do Ceará (UFC) \\ amandajfmoura@gmail.com
}

\section{RESUMO}

Em 1974, em crônica publicada no Jornal do Brasil, Carlos Drummond de Andrade questiona se a poesia não seria um estado de infância. Tal reflexão anima o presente estudo, o qual almeja revisitar esse topos recorrente na literatura e investigar como manter estreitos os laços entre a linguagem poética e as crianças, considerando o potencial sensível dos pequenos. Como objeto de estudo, tomamos A caligrafia de dona Sofia (2007), escrito e ilustrado por André Neves, a fim de examinar os artifícios visuais e textuais utilizados na confecção do livro. Para cumprirmos nossa proposta, dialogamos com autores como Regina Zilberman (2005), que excursiona pela história da poesia na literatura infantil brasileira; Nelly Novaes Coelho (2000), que examina procedimentos formais relativos à poesia voltada aos pequenos; e Rafael Sánchez-Mateos Paniagua (2018), que salienta o potencial revolucionário das ações infantis, irmanando-as ao próprio fazer poético.

Palavras-chave: poesia, infância, $A$ caligrafia de dona Sofia.

\section{ABSTRACT}

In 1974, in a chronicle published in Jornal do Brasil, Carlos Drummond de Andrade questions if poetry would not be a childhood state. Such reflection encourages the present study, which aims to revisit this recurring issue in literature and investigate how to keep the links between poetic language and children close, considering the sensitive potential of the little ones. As object of this investigation, we analyse the book " $A$ caligrafia de dona Sofia" (2007), written and illustrated by André Neves, in order to examine the visual and textual artifices used in the making of his work. To fulfill our proposal, we establish a dialogue with authors such as Regina Zilberman (2005), who tours the history of poetry in Brazilian children's literature; Nelly Novaes Coelho (2000), who examines formal procedures related to poetry aimed at the little ones; and Rafael Sánchez-Mateos Paniagua (2018), who emphasizes the revolutionary potential of children's actions, placing them within the poetic craft itself.

Keywords: poetry, childhood, A caligrafia de dona Sofia. 


\section{"Será a poesia um estado de infância?"}

Pensar a natureza mais íntima da poesia é o que anima a escrita de Os filhos do barro, livro de Octavio Paz. O autor mexicano compreende que o poema nasce de uma história, de uma sociedade, todavia tem poder de contradizê-la, produzindo, de tal modo, uma anti-história. O desejo do poema seria, afinal, abrir uma fenda em seu tempo e instaurar uma outra temporalidade.

Paz entende de que a poesia se constitui como um acontecimento primevo, inaugural, o qual remete ao tempo mítico, "o tempo de antes do tempo, o da 'vida interior', que reaparece no olhar da criança, o tempo sem datas" (PAZ, 1984, p. 67). O poeta seria, portanto, aquele cujo olhar desembota as imagens do mundo e as reinaugura em uma linguagem devolvida à infância, linguagem imantada de magia, novidade e brinquedo.

É visitando esse topos que Carlos Drummond de Andrade escreve, em 20 de julho de 1974, no Jornal do Brasil, uma crônica intitulada "A educação do ser poético", apontando a relação entre a infância e a poesia. Sem preocupação com as determinações do cotidiano, tampouco com normas prévias, a poesia e a meninice concebem uma experiência de liberdade a partir das palavras e dos sentidos, criando um fecundo espaço de invenção e descoberta no coração humano.

Por que motivo as crianças, de modo geral, são poetas e, com o tempo, deixam de sê-lo? Será a poesia um estado de infância relacionada com a necessidade de jogo, a ausência de conhecimento livresco, a despreocupação com os mandamentos práticos de viver - estado de pureza da mente, em suma? 
Acho que é um pouco de tudo isso, se ela encontra expressão cândida na meninice, pode expandir-se pelo tempo afora, conciliada com a experiência, o senso crítico, a consciência estética dos que compõem ou absorvem poesia (DRUMMOND, 1974).

Drummond questiona se não seria a infância um estado de poesia, uma vez que o mundo infantil se elabora no campo poético, e busca compreender os motivos de ruptura entre o sujeito e esse seu estado natural. Para o poeta de Itabira, a maneira como a escola apresenta a poesia aos pequenos, com um viés de instrução ou moralização, pode ter como efeito o afastamento.

\begin{abstract}
Mas, se o adulto, na maioria dos casos, perde essa comunhão com a poesia, não estará na escola, mais do que em qualquer outra instituição social, o elemento corrosivo do instinto poético da infância, que vai fenecendo, à proporção que o estudo sistemático se desenvolve, até desaparecer no homem feito e preparado supostamente para a vida? Receio que sim. A escola enche o menino de matemática, de geografia, de linguagem, sem, via de regra, fazê-lo através da poesia da matemática, da geografia, da linguagem (DRUMMOND, 1974).
\end{abstract}

De fato, a relação entre poesia e infância, no Brasil, teve seu início marcado por uma preocupação didática, embora o decorrer dos anos tenha modificado positivamente alguns pontos dessa realidade. Conforme esclarece Regina Zilberman em seu artigo " $E$ para a poesia, não vai nada?"'i (2005), os poemas estiveram presentes desde o começo da literatura infantil brasileira, tendo, no início do século XX, Francisca Júlia e Olavo Bilac como dois de seus principais expoentes, que publicaram, respectivamente, o Livro da infância (1899) e Poesias infantis (1904). Ocorre que, por muito tempo, a poesia brasileira feita para crianças possuiu direcionamentos fortemente educativos, acentuando instituições como família, religião e pátria. 
Houve, contudo, mudanças positivas nas últimas décadas, sobretudo a partir dos anos 1980. Zilberman (2005) aponta que a poesia para crianças constitui-se com mais vigor a partir desse final de século, em versos que apresentam um tema tão caro aos pequenos: a diversão. Nesse sentido, é exemplar o livro Poemas para Brincar, de José Paulo Paes, publicado em 1990, obra em que o escritor indica, dos pontos de vista temático e formal, os enlaces entre o brincar e o escrever.

\begin{abstract}
Poemas para Brincar, de José Paulo Paes, talvez seja o texto que melhor esclarece o que significa escrever versos para crianças e esperar que o leitor aprecie, pois o escritor estabelece uma conexão entre brincar e escrever. O conceito que formula destaca o ângulo lúdico presente em todo o poema, não apenas naquele dirigido à criança; mas as comparações propostas referem-se ao universo infantil, pois são os pequenos que brincam com bola, papagaio ou pião, sugerindo que a diversão e o jogo se evidenciam melhor em textos orientados para eles. $\mathrm{O}$ autor exercita-se na brincadeira, que, no caso, aparece por meio da repetição das consoantes bilabiais oclusivas - o b e o p - de brincar, bola, papagaio e pião. Como o poeta está fazendo poesia ao falar dela, emprega conscientemente os recursos que reconhece como próprios ao gênero em que se exprime (ZILBERMAN, 2005, p. 129).
\end{abstract}

Se, por um lado, a publicação de poesia voltada ao público infantil tornou-se cada vez mais expressiva, por outro lado, o questionamento de Drummond se mantém atual. Ora, a poesia permanece menos considerada que a prosa em aulas de português e literatura nas escolas brasileiras, de modo que o convívio das crianças com a dicção poética é defasado. Diante desse cenário, como cuidar, então, para que a criança permaneça em intimidade com a poesia? Drummond propõe que a escola considere, em primeira instância, o prazer e a fruição do texto, sua tessitura de magia.

O que eu pediria à escola, se não me faltassem luzes pedagógicas, era considerar a poesia como primeira visão direta das coisas e, depois, 
como veículo de informação prática e teórica, preservando em cada aluno o fundo mágico, lúdico, intuitivo e criativo, que se identifica basicamente com a sensibilidade poética (DRUMMOND, 1974).

Guardando essa preocupação em estreitar laços entre poesia e infância, os escritores têm criado obras cujas propostas consideram cada vez mais o potencial sensível da criancice. Neste estudo, pretendemos discutir uma delas: A caligrafia de dona Sofia (2007), livro terno, que parece querer preservar na poesia o estado de infância.

\section{Os espaços poéticos em A caligrafia de dona Sofia}

A caligrafia de dona Sofia (2007) teve como escritor e ilustrador o artista André Nevesii, que tem se consolidado como um importante autor de livros infantis. Nascido em Recife (PE), André estudou Artes Plásticas e atua como escritor, ilustrador e arteeducador, tendo seu trabalho reconhecido em diversas premiações. Em 2001, com sua obra Seca, recebeu o "Prêmio Luís Jardim", de melhor livro de imagem. Em 2003, como escritor, foi agraciado com menção honrosa no Prêmio Jabuti com Obax. Em 2004, recebeu o Prêmio Açorianos de Melhor llustração. Além disso, parte de sua obra recebeu selos "Altamente Recomendável", concedidos pela Fundação Nacional do Livro Infantil e Juvenil. Em 2017, venceu o 3ㅇ lugar na categoria Ilustração de Livro Infantil ou Juvenil, do Prêmio Jabuti, com a obra Nuno e as Coisas Incríveis. Teve vários títulos publicados no Brasil e na Europa e participou, junto a outros ilustradores do mundo, de dois livros de contos na Itália. Também esteve em mostras e exposições de ilustração no Brasil e no exterior, tais como a XX Mostra Internazionale d'illustrazione per l'infanzia e a Bienal Ilustração Bratislava. 
Situando-se como ponto importante dessa premiada trajetória, A caligrafia de dona Sofia (2007), que traz novidades nos planos da forma e do conteúdo, narra a história de uma professora aposentada que mora no alto de uma colina e, apaixonada por poesia, decora com versos os espaços de sua casa: as paredes, os cantinhos das janelas... Certo dia, percebe que não há mais espaço para os poemas, então decide escrevê-los com sua caligrafia caprichada em cartões aos seus vizinhos. Para essa tarefa, conta com seu amigo Ananias, o carteiro da cidade.

Figura 1 - Capa

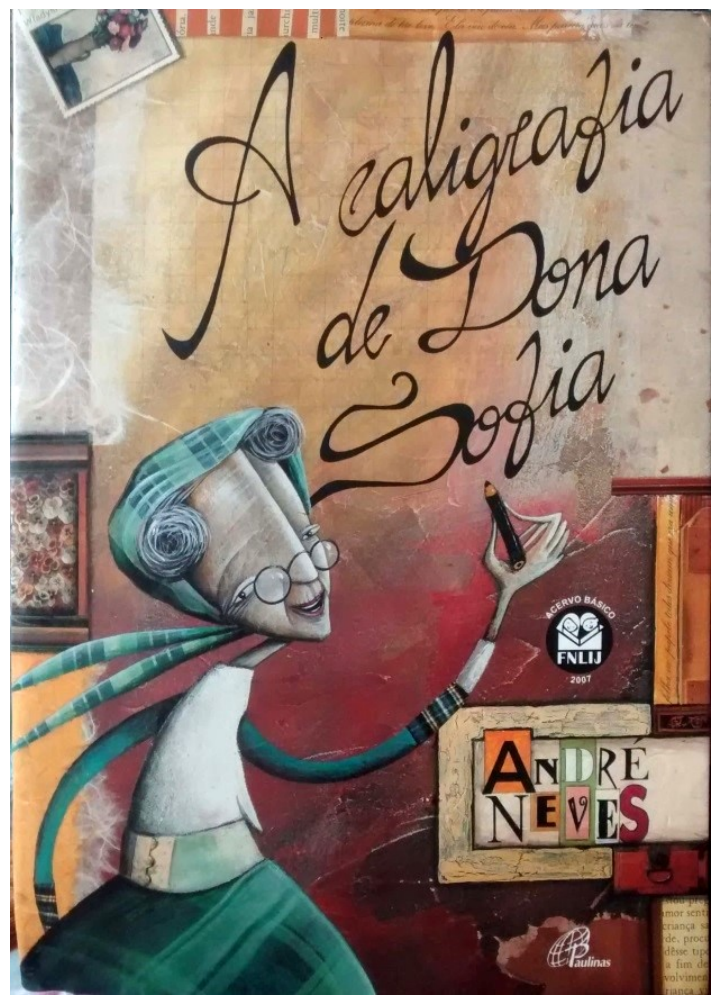

Logo em seu início, antes mesmo que a narrativa em prosa se desenvolva, a obra traz, em um arranjo gráfico inesperado, poemas de alguns autores: Roseana Murray ${ }^{\mathrm{iii}}$, Fernando Pessoa e Fernando Paixão ${ }^{\text {iv }}$. Há também um último, logo acima de uma gravura com o nome de André Neves, como que indicando se tratar de um poema seu. Em todos, 
as temáticas versam acerca do universo poético: do livro, da poesia, do escritor e do ato de escrever.

No poema de Roseana Murray, o livro surge como sensação e espaço: descanso, casa, fluxo de mar e rio, gruta encantada. Nessa morada de palavras mágicas, o leitor é levado pelas águas da poesia, a própria imaginação, que quebra a rigidez do cotidiano e mobiliza a sensibilidade.

É a partir da palavra poética que o escritor performa ou cria sua dor, como lemos em "Autopsicografia", de Fernando Pessoa, e, ao leitor, ocorre semelhante acontecimento, uma vez que ele se reconhece naquelas palavras, as quais não dizem respeito a uma única pessoa, mas a todos nós, a toda a existência humana, visto que a literatura "é a casa de tudo", como diz um verso de Roseana Murray.

Com o poema de Fernando Paixão, tem-se a inclinação da poesia em fazer do poeta um infante. Se "O poeta/escreve poesia/ para ser criança/ todo dia", os versos surgem, como propôs Drummond, em um estado de infância, em uma experiência em que revitaliza a linguagem. Assim, a poesia roda ao vento, "gira invento a todo momento/ roda palavra na boca/ enrola rima ponta na língua", habilitando um mundo de brinquedo e reinação. 
Figura 2 - Páginas 2 e 3

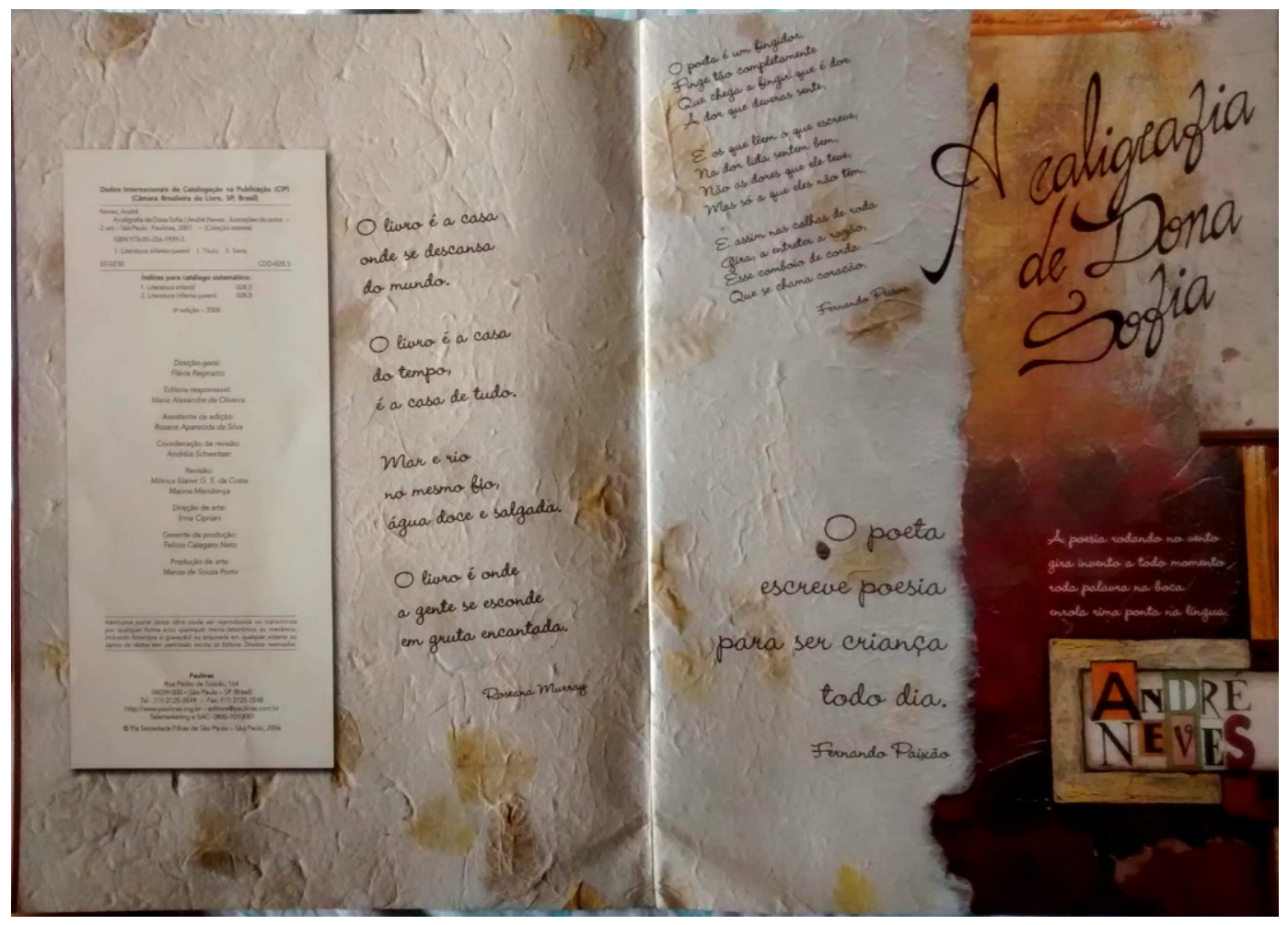

Importante observar também, nestas mesmas páginas, as ilustrações, em que se vê diversas frases caligrafadas na madeira de um móvel e no detalhe do que parece ser uma janela da casa de dona Sofia. A presença de texto nesses espaços indica um movimento que perpassa toda a obra: a persistência de ler e escrever em qualquer lugar onde se possa, em um processo de preencher uma página, uma casa, uma cidade, uma vida. De tal modo, não há lugar fixo para a poesia porque ela está em toda parte. 
Figura 3 - Detalhes da página 3

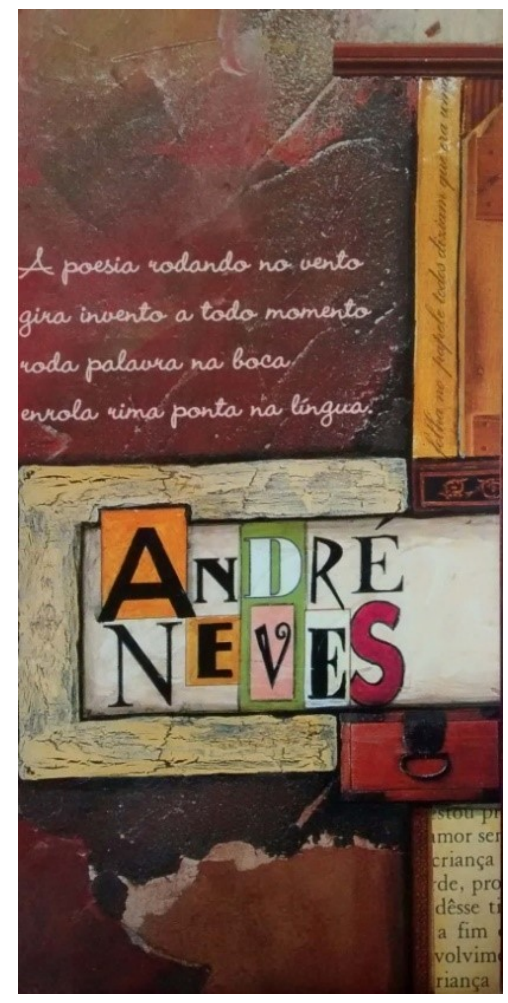

Ainda quando não há versos identificáveis de algum poeta, o projeto gráfico privilegia o mundo das letras, da leitura e do livro, conforme verificamos nas ilustrações abaixo: nos livros empilhados em cima do móvel, no ato de escrever, no papel de embrulho e na estradinha de terra pela qual passam os carros que sobem a colina onde a professora habita. 
Figura 4 - Página 11

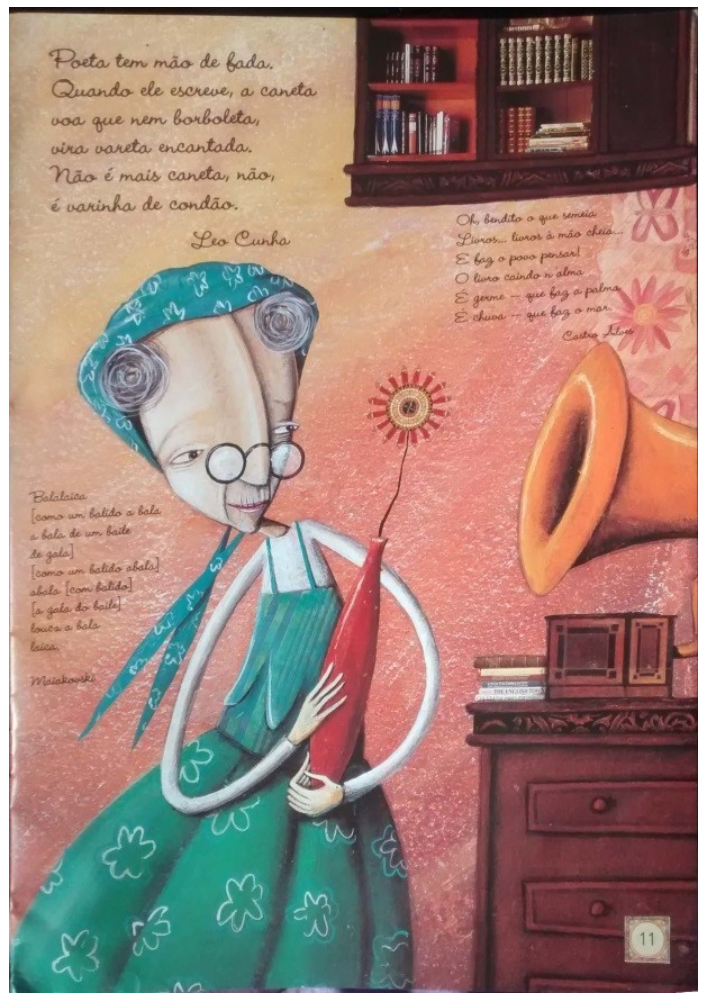

Figura 5 - Página 13

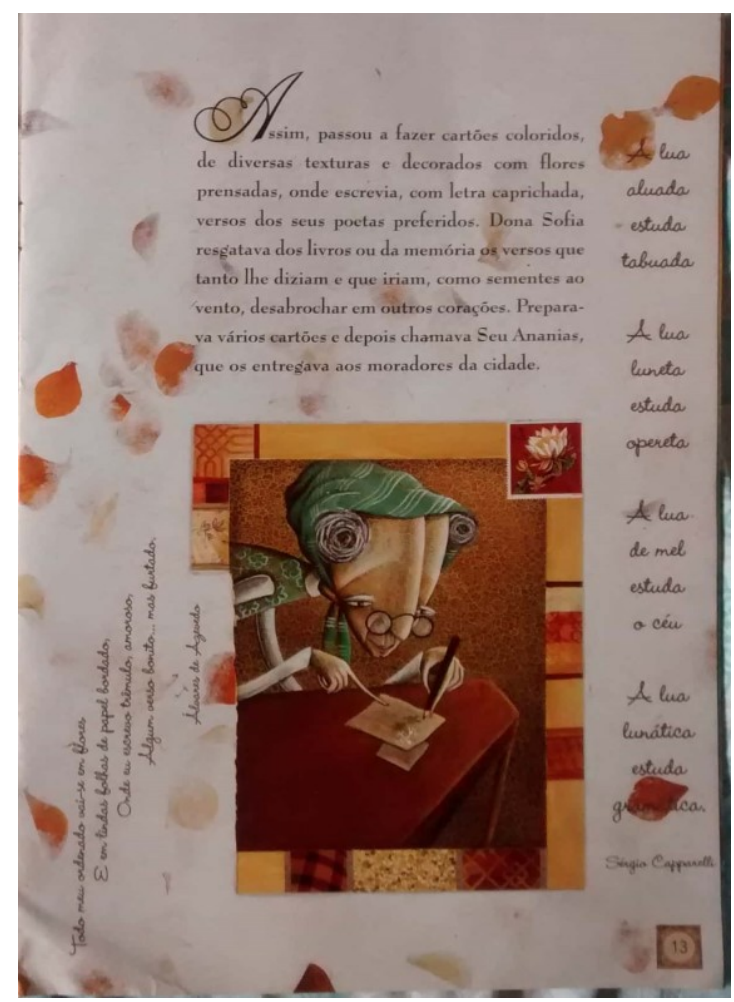


Figura 6 - Detalhe da página 24

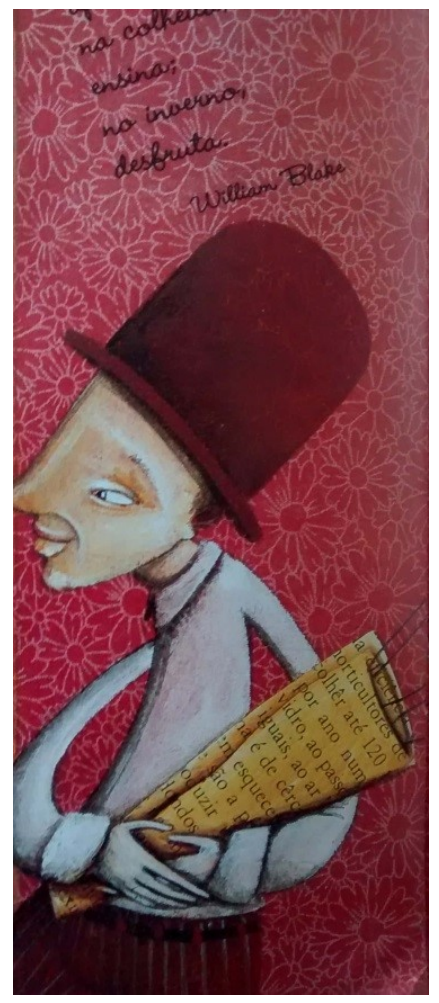

Figura 7-Detalhe da página 36

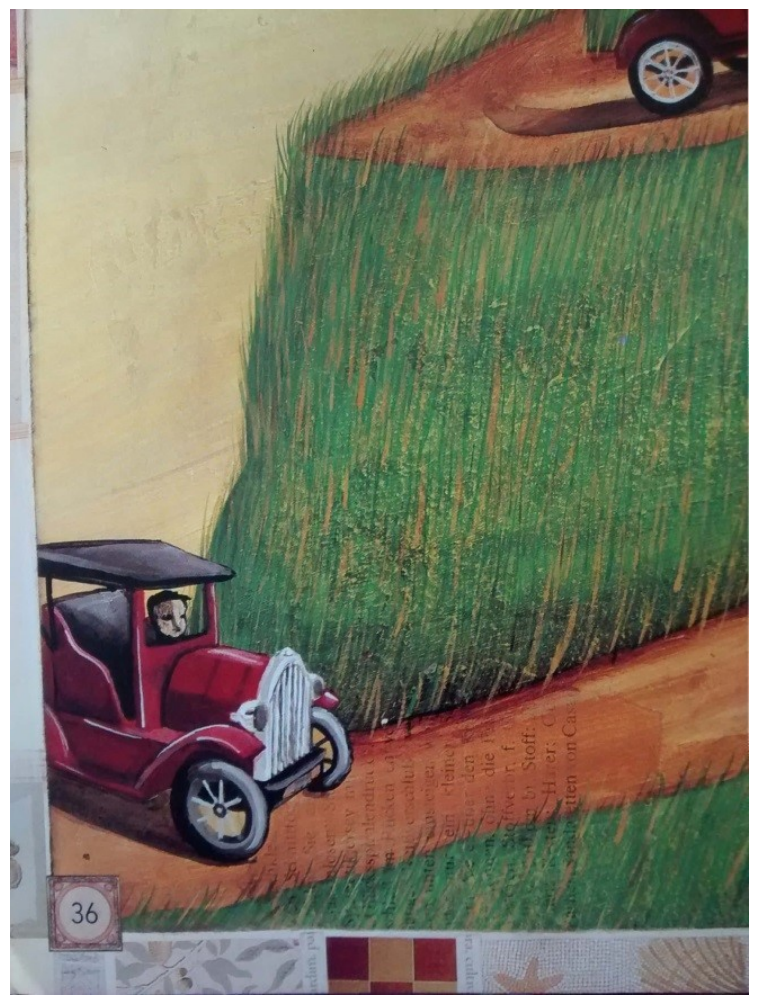


Em A caligrafia de dona Sofia (2007), nem sempre há uma orientação de que poema deve ser lido primeiro, ou mesmo se a leitura da prosa deve anteceder a da poesia. Instaura-se uma espécie de caos e desordenamento, como no quarto desarrumado de uma criança. Todavia essa desierarquização não seria capaz de criar novos vínculos e possibilidades semânticas a cada leitura?

Como se concordasse com as reflexões de Drummond sobre o embrião poético contido na infância, a obra parece apostar que a criança não carece de instruções rígidas para estar com os poemas. Sendo a poesia uma diversão, ela invade a narrativa e subverte a fixidez dos modos de apresentação.

O fato é que a poesia reverbera em múltiplas camadas: atua como ornamento na morada de dona Sofia e como ilustração na obra de André Neves. Conforme demonstra a figura abaixo, os poemas desenham o cenário, endereçando à imaginação do leitor um lugar belo, alto como montes e colinas, e cercado de natureza. Os versos de Francisca Júlia desvelam a morada de dona Sofia como um lugar recôndito, "um ninho feliz e obscuro". 
Figura 8 - Páginas 6 e 7

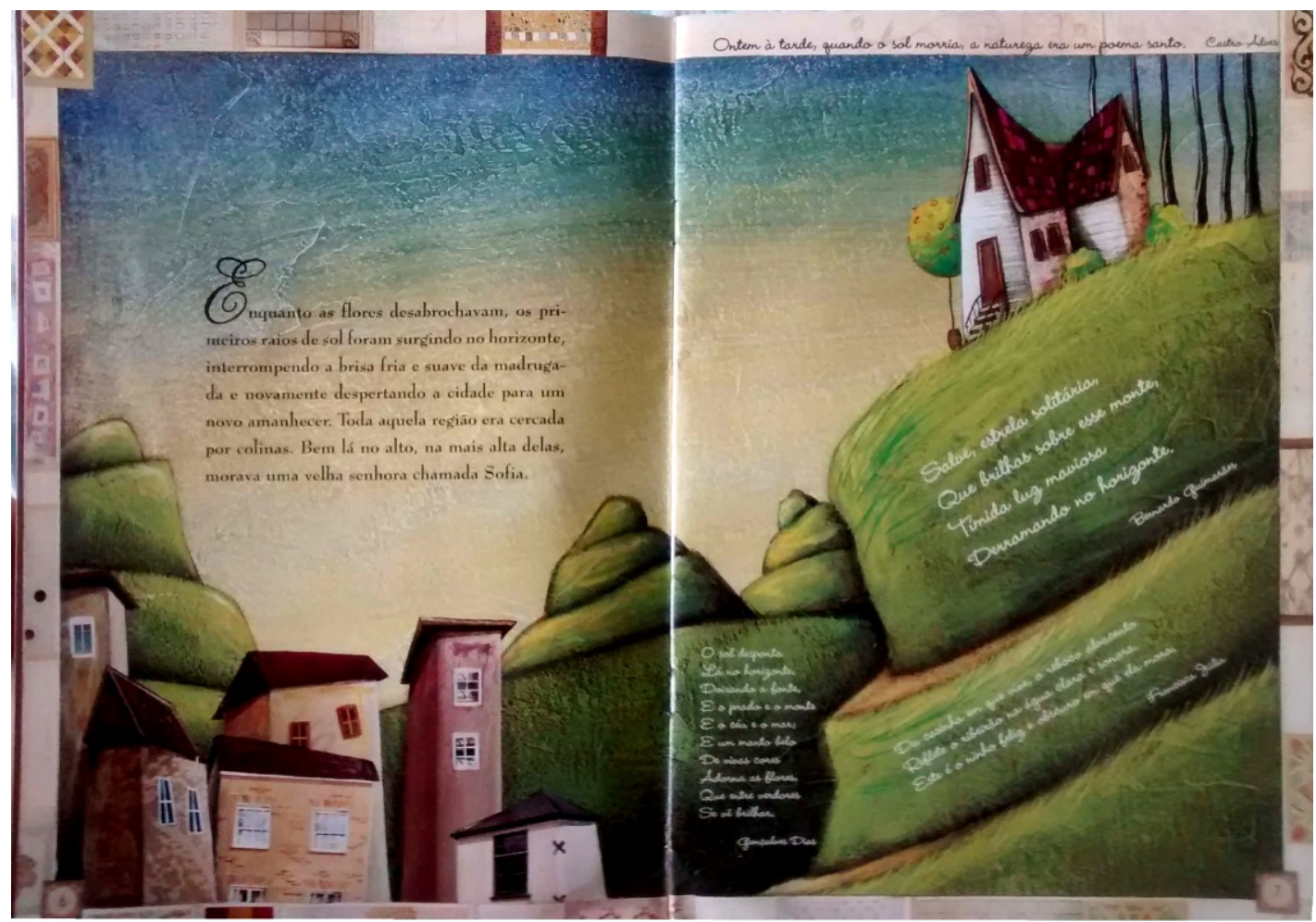

Os versos compõem também uma antologia poética para o leitor, introduzindo a criança em um rico repertório cultural das letras. Na figura anterior, podemos observar quatro poetas: Castro Alves, Gonçalves Dias, Bernardo Guimarães e Francisca Júlia. Os três primeiros são autores românticos amplamente revisitados nas escolas e nos cursos de letras, especialmente Castro Alves e Gonçalves Dias. Mas é uma grata surpresa encontrar uma estrofe de Francisca Júlia, que, embora tenha transitado entre o parnasianismo e o simbolismo, se mantém desconhecida mesmo nas universidades, esquecida por muitos estudantes e professores de literatura.

Em uma breve apresentação da autora, podemos citar seus dois volumes de poesia, Mármores (1895) e Esfinges (1903), além dos infanto-juvenis Livro da infância (1899) e Alma infantil (1912). Dos livros adultos, o primeiro livro é considerado mais parnasiano, enquanto o segundo, além de trazer poemas do primeiro, apresenta novos 
escritos com influências simbolistas, valorizando uma temática mais mística e contemplativa.

Curioso notar que os versos contemplados por André Neves são oriundos do poema "Rústica", presente no livro Esfinges (1903), que não é necessariamente dirigido aos pequeninos. Esse procedimento, aliás, é recorrente em A caligrafia de dona Sofia (2007): o autor apresenta versos supostamente adultos, mas que podem encontrar ressonância nas crianças.

Neves dispõe, lado a lado, poetas cujas origens, temáticas e procedimentos são bastante díspares. Autores canônicos, como Florbela Espanca e Carlos Drummond de Andrade, dividem a mesma página com outros menos conhecidos, como Elias José, ${ }^{\vee}$ Ricardo Silvestrin ${ }^{\text {vi }}$ e Sérgio Napp. ${ }^{\text {vii }}$ Nenhum deles se dirige especialmente aos pequenos, embora a seleção dos poemas tenha sido cuidadosa em buscar versos que podem ser lidos pela maioria das crianças.

Figura 9 - Páginas 12 e 13

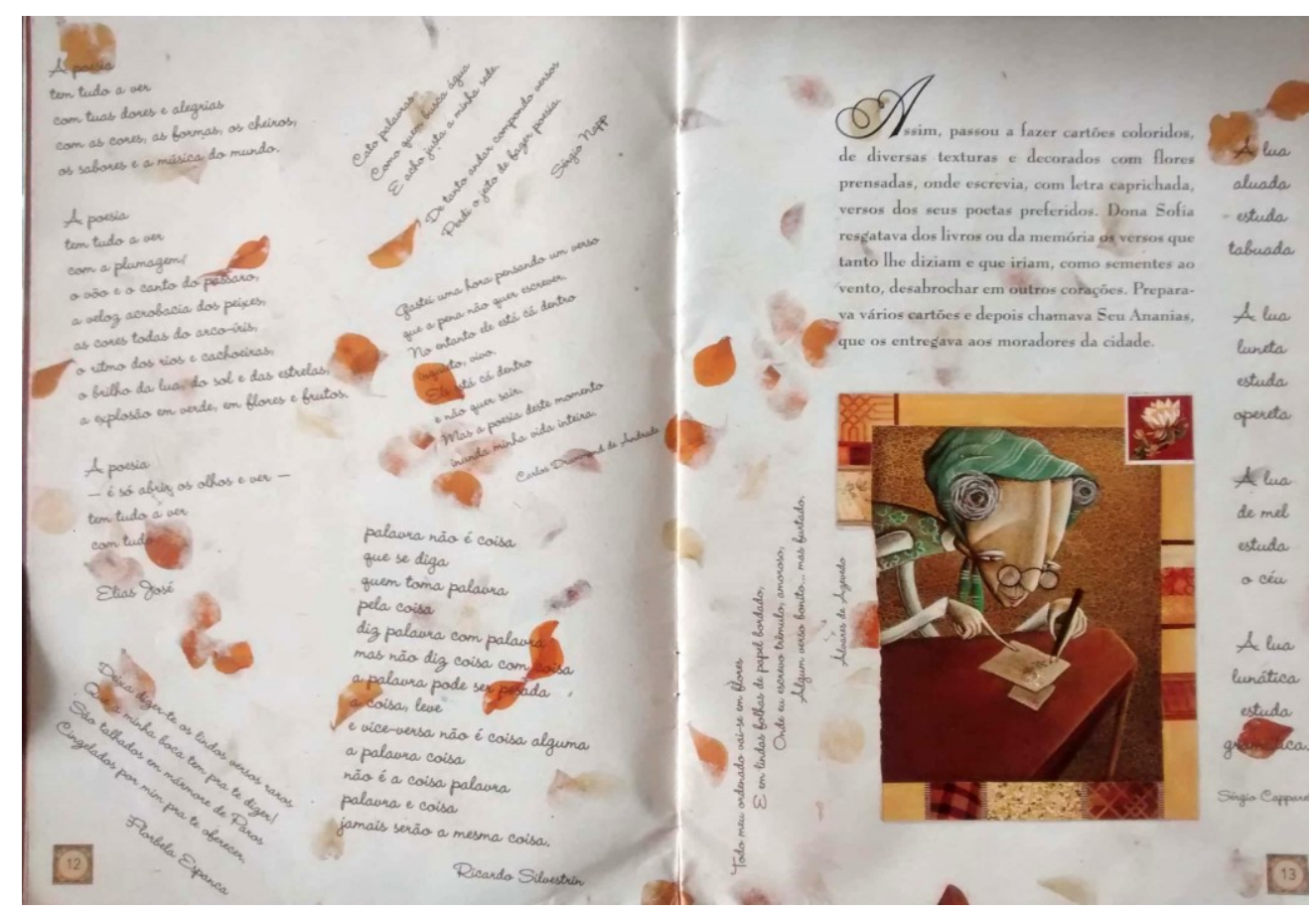


As estrofes escolhidas não se apoiam no que Nelly Novaes Coelho (2000, p. 231) chama de "clichês poéticos" - uso frequente de diminutivos, construções sintáticas repetitivas e incentivo aos ensinamentos ou às boas maneiras -, os quais poderiam estabelecer uma barreira quanto à revelação do mundo prazeroso e mágico da linguagem.

$\mathrm{Na}$ verdade, os poemas abordam o próprio fazer poético, a relação entre palavras e coisas e a existência da poesia em nosso mundo, em nossas vidas. A presença de bichos e elementos da natureza pode atuar como um fator de aproximação entre as crianças e esses versos que, embora tendam a manter uma linguagem mais simples e acessível, tratam de temas algo abstratos. Mesmo um poeta como Álvares de Azevedo, cuja dicção é ultrarromântica e, por vezes, alusiva à morbidez, não constitui embaraço algum neste livro infantil, pois é contemplado em uma estrofe que aborda a natureza, a literatura e o amor.

Todo o meu ordenado vai-se em flores

E em lindas folhas de papel bordado

Onde eu escrevo trêmulo, amoroso,

Algum verso bonito... mas furtado.

De tal modo, a poesia vai tomando conta da narrativa e da vida de todos, pois, conforme as páginas passam, os moradores da cidade e o leitor conhecem novos poetas.

Um personagem que experimenta uma grande transformação é Ananias. Ao receber um cartão poético com um poema de Casimiro de Abreu, o carteiro se torna leitor de poesia e começa a escrever seus próprios versos. 
Figura 10 - Página 37

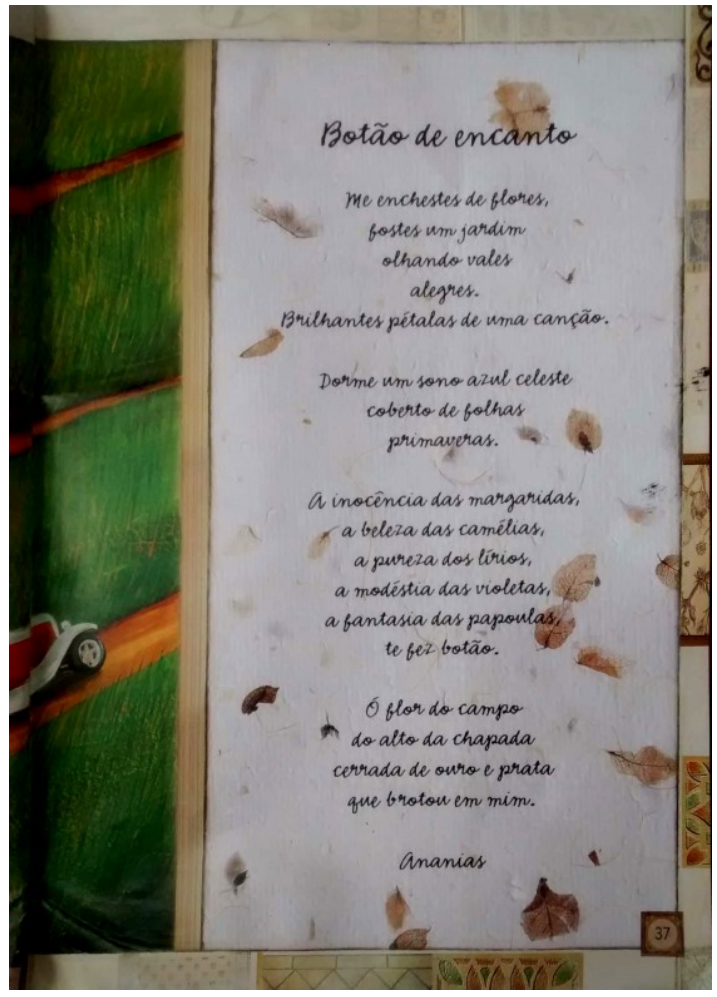

A personagem de Sofia, por sua vez, relaciona-se bastante ao saber, e suas principais características dizem respeito ao mundo das letras e do ensino. Concomitantemente a isso, as ilustrações reforçam essa sensação, apresentando uma senhora de óculos que escreve nas paredes, remetendo ao gesto professoral de usar o giz no quadro negro. Essa seriedade, contudo, é sopesada, pelas ideias de movimento e troca.

Observemos, primeiramente, o trânsito entre as linguagens de prosa, poesia e imagem, que dialogam entre si e com a narrativa para tensionar a construção dos sentidos do texto. Em segundo lugar, os poetas das mais diversas origens e épocas ocupam um mesmo livro, uma mesma página, rompendo noções de hierarquia, o que resulta na percepção de que não há caminhos fixos para o encontro com a poesia, de modo que o pequeno leitor pode delinear suas preferências de modo mais autônomo, 
colhendo as palavras poéticas em seu ritmo e construindo seu cânone pessoal. Por fim, percebemos os fluxos entre os personagens da narrativa, pois se, no início, é apenas a professora quem escreve, ao final, a população passa a enviar cartas à dona Sofia, de modo que a literatura não estaria circunscrita ao âmbito do conhecimento, mas seria especialmente uma prática que agrega as pessoas. Ora, o saber da professora não se paralisa no topo de uma colina ou em um lugar exato da folha de papel: ele é da ordem da comunhão e da partilha.

Figura 11 - Página 4

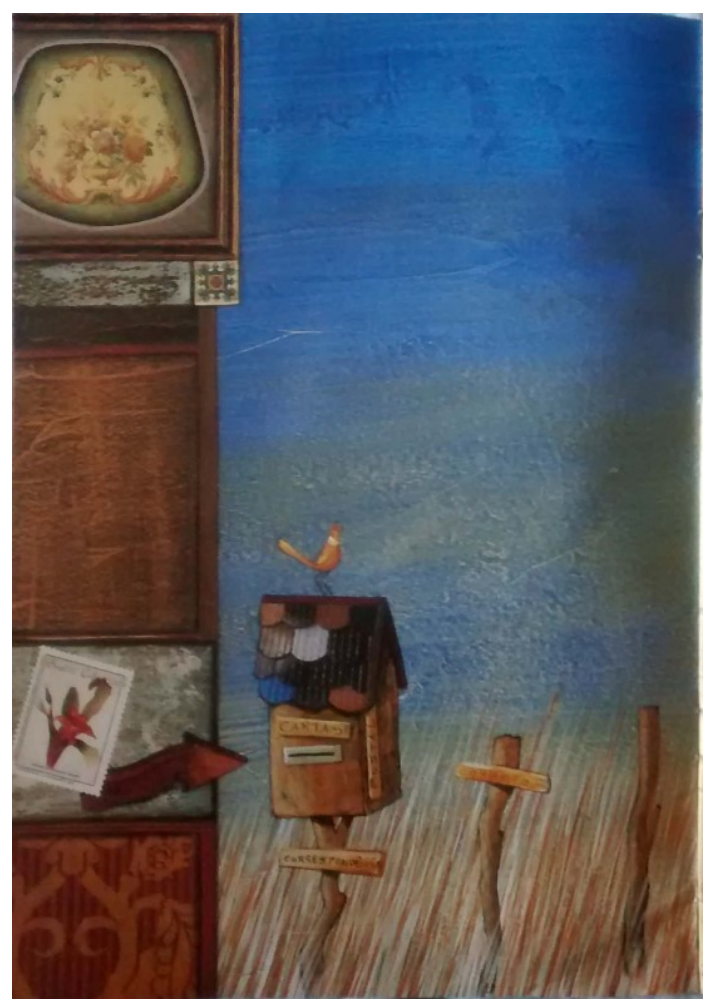

Por fim, as últimas folhas trazem uma seção inabitual em obras infantis: "REFERÊNCIAS BIBLIOGRÁFICAS", contendo, em normas da ABNT, as informações relativas a cada um dos poemas visitados no livro. Podemos supor uma explicação de cunho prático, que diz respeito à inserção da criança no universo livresco, 
proporcionando o aprendizado à identificação de autores e obras, bem como a possibilidade de, quando quiser, recuperá-los.

Há, ainda, uma outra explicação que pode somar-se a essa, complementando-a: consideremos a educação do ser poético, que nunca está finalizada, mas se dá em um processo contínuo de convivência com a poesia. Nesse sentido, A caligrafia de dona Sofia (2007), se amplia com a curiosidade do leitor em buscar os autores que surgem nas páginas, crescendo com a criança e convidando-a à releitura - afinal, nas palavras de Machado de Assis, "Livros relidos são livros eternos".

Figura 12 - Detalhe da contracapa

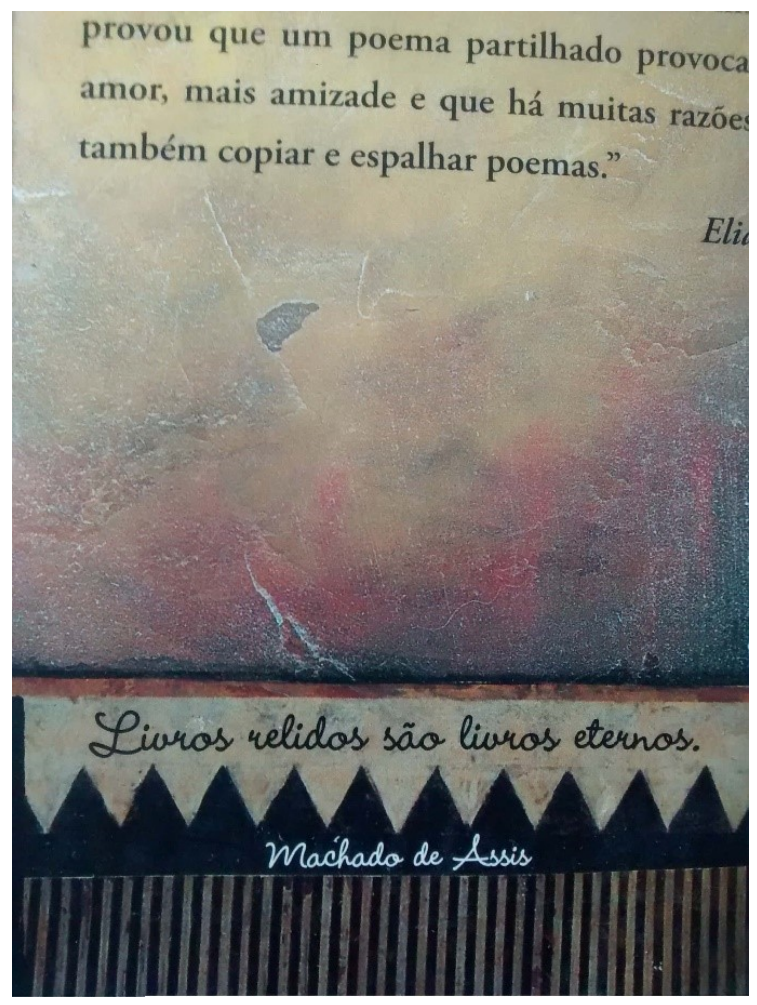




\section{Infância, poesia e liberdade}

Considerado altamente recomendável, A caligrafia de dona Sofia (2007) recebeu o selo da Fundação Nacional do Livro Infantil e Juvenil (FNLIJ) e vem sendo lido por crianças do Brasil inteiro. Não é de se espantar o reconhecimento obtido, uma vez que, com um enredo aparentemente simples, André Neves escreve e ilustra um livro engenhoso. Ora, embora se constitua como uma narrativa em prosa, a obra incorpora, de maneiras impensadas, poemas das mais diversas estéticas. Além disso, a disposição gráfica dos poemas, que estimula a criança a virar o livro para a esquerda, a direita ou a colocá-lo de cabeça pra baixo, promove também a sensação de jogo e divertimento.

Os poemas apresentados não possuem uma dicção direcionada à criança, contudo o autor os agrega e proporciona que os pequenos tenham acesso a um repertório poético valioso. Nesse sentido, cabe perguntar: a poesia para crianças precisa necessariamente ser infantil? A caligrafia de dona Sofia (2007) responde apontando a tenuidade entre essas fronteiras que divisam a literatura infantil e a adulta. De tal modo, a educação do ser poético pode como ter aliados sentimentais os poemas ditos adultos, a partir de uma seleção cuidadosa de textos e trechos que dialoguem com o universo infantil ou, talvez, com o universo de qualquer ser humano, em qualquer idade.

Essa possibilidade questiona os significados algo condescendentes que com frequência conferimos às crianças, isto é, a caracterização que fazemos da infância como um momento de menor capacidade, o qual demandaria, assim, ilimitada tutela. Em "Suscitar o verdadeiro estado de exceção infantil", Rafael Sánchez-Mateos Paniagua refuta essas concepções limitadoras atribuídas aos pequenos. 
Teríamos que pensar no fato de que, na infância, essa força de pensaragir ainda não se rompeu, e a criança pequena vai com garra, incorpora suas ideias infantis a gestos que um momento de oportunidade permite levar a cabo. A ousadia da liberdade e o atrevimento de saber consistem em dar esse passo. Esse vínculo, essa adesão ao mundo e ao que ele tem de possível, é o que vincula o fazer da criança com a ação revolucionária e ação artística (PANIAGUA, p. 10).

A seu modo, as palavras de Paniagua parecem ilustrar os procedimentos de André Neves e selar com Drummond a compreensão de que a infância é guiada, sobretudo pela ousadia e pelo atrevimento, os quais mantêm interligados o pensar e o agir, irmanando o fazer infantil às ações revolucionárias e artísticas. A humanidade, assim sendo, encontrase com a poesia justamente na potência imprevisível da invenção e do começo, na infância. E se há caminho para a comunhão da criança com a poesia, cremos que essa experiência deve passar, antes de tudo, pelo prazer.

\section{Referências}

ANDRADE, Carlos Drummond de. A educação do ser poético. Jornal do Brasil. 20 jul. 1974.

COELHO. Nelly Novaes. Literatura infantil: teoria, análise, didática. São Paulo: Moderna, 2000.

NEVES, André. A caligrafia de dona Sofia. São Paulo: Paulinas, 2007.

PANIAGUA, Rafael Sánchez-Mateos. Suscitar o verdadeiro estado de exceção infantil. Caderno de Leitura. n. 77. Edições Chão da Feira. Disponível em: <http://chaodafeira.com/wp-content/uploads/2018/05/cad77.pdf>. Acesso em: 4 fev. 2019. p. 1-14.

PAZ, Octavio. Os filhos do barro. Rio de Janeiro: Nova Fronteira, 1984.

ZILBERMAN, Regina. E para a poesia, não vai nada? In: ZILBERMAN, R. Como e por que ler a literatura infantil brasileira. Rio de Janeiro: Objetiva, 2005. 
Recebido em 4 de fevereiro de 2019.

Aceite em 8 de março de 2019.

\footnotetext{
' No referido ensaio, aponta-se Olavo Bilac como o percursor da poesia na literatura infantil brasileira. Todavia, em 1899, antes da publicação de Bilac, a poeta Francisca Júlia escreveu uma obra voltada às crianças: o Livro da Infância, o qual trazia, além de textos em prosa, alguns poemas.

ii As informações biográficas foram retiradas do blog pessoal de André Neves, disponível em: <http://confabulandoimagens.blogspot.com>. Acesso em: 16 jun. 2018.

iii Roseana Murray nasceu em 1950, no Rio de Janeiro e formou-se em Língua e Literatura Francesa. Tendo mais de cem títulos publicados, é autora de livros de poesia e prosa voltados aos públicos das mais diversas faixas etárias.
}

${ }^{\text {iv }}$ Fernando Paixão nasceu em 1955, na aldeia portuguesa de Beselga, e transferiu-se ao Brasil em 1961. Formou-se em jornalismo pela USP, onde leciona Literatura no Instituto de Estudos Brasileiros.

`Elias José nasceu em Guaranésia, Minas Gerais, em 1936. Além de ter atuado como professor de Literatura Brasileira e Teoria Literária, foi também escritor, tendo publicado livros de contos, crônica, romance e poesia. Faleceu em Santos, em 2008.

${ }^{v i}$ Ricardo Silvestrin nasceu em Porto Alegre, em 1963. Em 1985, formou-se em Letras e publicou seu primeiro livro de poemas. Atualmente, tem mais e vinte títulos publicados.

vii Sergio Napp nasceu em Giruá, no Rio Grande do Sul, em 1939. Foi escritor, letrista e engenheiro civil. Faleceu em 2015. 